\title{
肺癌の治療に関する臨床的研究
}

\author{
第 $\quad 2$ 編 \\ 肺癌患者の細胞性免疫能に関する研究一癌化学療法症 \\ 例におけるその経時的変動と溶連菌剂の効果について一 \\ 岡山大学医学部第 2 内科教室（主任：平木潔教授） \\ 大学院生 藤 井昌史 \\ (昭和51年 3 月 30 日受稿)
}

内容目次

第 1 章 緒 言

第 2 章 対象ならびに方法

第 1 節 対象患者.

第 2 節 実験方法.

第 1 項 リンパ球幼若化反応.

第 2 項 ツベルクリン反応.

第 3 項 Leucocyte migration inhibition test

第 4 項 末梢リンパ球数.

第 3 章 成 . 縝

第 1 節 リンパ球纤若化反応.

第 1 項 測定条件, 測定精度ならびに正常値に 関する検討。

第 2 項 肺癌症例の治療前のリンパ球幼若化反 応阔する成績。

第 3 項 化学療法症例におけるリンパ球幼若化 率の変動にういて。

第 4 項 OK-432単独投与におけるリンパ球幼 若化率の変動について.

第 2 節 ツベルクリン反応.

第 1 項 治療前のッベルクリン反忘について.

第 2 項化学察法による変動,主として OK-432 併用，非併用の比較.

第 3 節 末梢リンバ球数。

第 4 節 肺癌患者におけるリンパ球幼若化反応, ッベルクリン反応, 末梢リンバ球数の相 互関係ならびにてれらの総合評価につい $\tau$.

第 5 節 leucocyte migration inhibition test
第 1 項 至適抗原濃度および再現性に関する検 討.

第 2 項 肺癌患者, 非肺癌々症例, 良性呼吸器 疾患における検討。

第 3 項 化学㙩法による migration index の変 動について。

第 4 項 OK-432 単独投与における migration index の変動について.

第 6 節 肺演化学療法症例䎲おける OK-432投与 群, 非投与群の生存期間に関する検討.

第 5 章 総括ならびに考案.

第 6 章 結論

\section{第।章 緒言}

担癌生体では一般に網内系機能が低下しているこ とは古くから認められており”，その進行度と並行し て変動し低下しているものはその予後も悪いとされ ていだ! その後腫煬に対する兔疫反応の主体がリン パ球（特にT細胞）を中心とする細胞免疫反态で あり，癌の進行とともにT細胞の機能低下をきたす ととが明らかにされてきた，また実験腫掦の多くに 腫湟特異的移植抗原（TSTA）の存在が証明され，

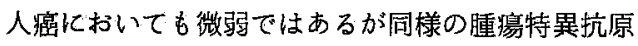
(TSA) が存在するととが知られており，特翼的細 胞免度反応関する検討がなされてきた。他方，B 細胞の産生に上る液性抗体の抗腫愓性に関する実験 もみられるが，液性抗体はむしろ細胞免度には不利 に作用する場合が多いと考えられている．そこで著 者も原発性肺演患者を中心に，T細胞のもつ非特異 的, 特異的細狍免疫能の parameter として末梢り 
ンパ球の in vitroにおける phytohemagglutinin (PHA) に対する幼若化反応 (幼若化反応), ッべ ルクリン反応 (ツ反), 末梢リンパ球数, leucocyte migration inhibition test(LMIT) について肺痛の 進展度，予後などとの相関性を検討し，さらに癌化 学療法や放射線療法による臨床経過とてれらのパラ メーターの推移との関係を知るととにより，てれら のパラメーターの臨床における有用性を検討した。 同時に肺癌患者に対し免疫賊活作用を有するとされ ている溶連菌剤 OK-432 投与した場合の幼若化反 応，ツ反，LMITに及ほすす影響について検討すると ともに, 溶連菌剤導入によろ免疫化学療法が行われ た肺癌症例の生存期間に関する検討を試み，本剂の 免疫療法剂としての有用性を検討した。

\section{第 2 章 対象ならびに方法}

\section{第 1 節 対象患者}

対象は当科入院中または外来通院中の肺癌患者で， 多くの症例が組織唁あるいは細胞診よる確診がなさ れている. 幼若化反応は肺癌应例 52 例, 健康人 46 例について, ッ反は肺㺃65例について, LMIT は肺 癌19例, 肺癌以外の悪性腫湟 8 例, 肺感染症 8 例, 健康人 7 例について検討した，化学療法に溶連菌剮 OK-432 を併用した肺癌症例の生存期間偣関する検 討では臨床病期 III，IV期のものを対象とし，OK-432 併用群21例，非併用群26例について生存期間の比較 を行った。

\section{第 2 節 実験方法}

以下に述べる方法で幼若化反応，ッ反，LMIT，末 梢リンパ球数の測定を行ったが，いずれも治療開始 前に実施した。さらに幼若化反応については OK-432 単独投与前後の推移と, 癌化学療法（主として前編 で述へた 5-fluorouracil, vincristine, bleomycin, cyclophosphamide おょび mitomycin C 併用 FOBEM療法) あるいは故射線療法化伴う変動，ま た OK-432 併用群, 非併用群における変動を検討し た.ッ反については化学㞠法に伴う推移を OK-432 併用群，非併用群にわけて比較検討した，LMITは 主として化学療法症例におうる変動を観察し, 若干 の症例について OK-432 投与前後の推移を検討した。

第 1 項 リンパ球奻若化反応.

Pellegrino ら" の開発した微量全血法に準し以下 の方法で行った. 図ー1に図示したでとくへパリン加 末梢血 $0.05 \mathrm{ml}$ に20\%牛胎児血清加 RPMI $16402 \mathrm{ml}$ を加え, PHA-P(Difco) $5 \mu 1$ を添加し, PHA-P
図 1 微量全血法によるリンパ球幼若化反応
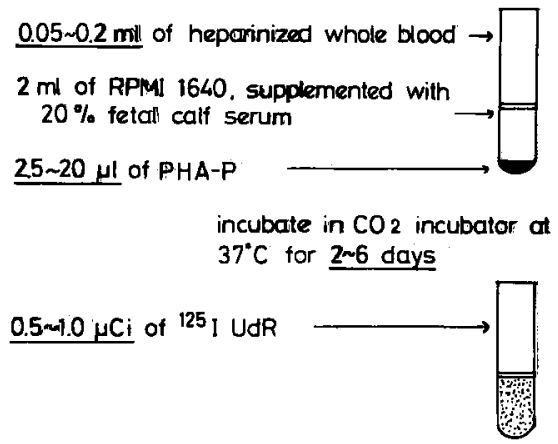

atter $2 \sim 10 \mathrm{hrs}$ incubation, cells were washed with saline solution counted in well-r-counter

Stimulation Index
( S.I.)

加えないものを対照とした．PHA-P添加, 非添加培 養液とも一検体についてそれぞれ triplicate とした が, これらを $\mathrm{CO}_{2}$ in cubator 内で37 ${ }^{\circ} \mathrm{C} ４$ 日間静 置培養後, ${ }^{125} \mathrm{I}$-deoxyuridine $0.5 \mu \mathrm{Ci}$ を加え, さら に 6 時間静置培美し, ${ }^{125} \mathrm{I}$-deoxyuridine を取りこま せた。培養䅂了後冷生理食塩水にて 3000 r. p. m. 亿 て 3 回遠沈洗雀し，リンパ球に取りとまれた deoxyuridine $の$ 放射活性を well 型 $\gamma$ counter で測 定し，下記のじとく $\mathrm{PHA}-\mathrm{P}$ 添加培養の平均放射活 性に対する非添加培養平均放射活性の比を stimulation index(S. I. )で表わした.

S. I. $=\frac{\text { PHA-P添加培羕の平均 C.P. } \mathrm{m}^{\prime}}{\text { PHA-P 非添加培盖の平均 C.P.m }}$

第 2 項 ツベルクリン反応.

原則として一般診断用精製ツベルクリン液 $0,1 \mathrm{ml}$ を前坨掌側に皮内注射し，48時間後に判定した。判 定は紅斑直径 0４ $\mathrm{mm}$ を(一)，5－9 mm (土)， $10 \mathrm{~mm}$ 以上党 (+), $10 \mathrm{~mm}$ 以上の紅斑に硬結を伴うも の $(\#)$ ，二重発赤あるいは水泡を伴うものを(卅)と し，(十)以上を陽性とした。なお経時的観察を行う 場合，一般䛦断用を用いて初回陰性の症例において は確診用のものを用い，それに対する皮府反応の推 移を検討した。

第 3 項 Leucocyte migration inhibition test (LMIT)

Clausen" の開発した agarose plate 法に基つくく 
Ax ら”の方法について検討を加え，以下の方法で測 定した.

まず agarose plate の作成方法について述べる. 蒸留水に $3 \%$ 相当の agarose (Behringwerke $A G$ ) を加元, autoclave にて减菌後 $42^{\circ} \mathrm{C} の$ water bath に保ち，同しく $42^{\circ} \mathrm{C}$ 加温した同容量の 2 倍濃度 Eagle medium と1/2容量の馬血清を加え $て$ agarose solution とした，従って agarose の最䅂濃度は1,2 \%，馬血清のそれは $20 \%$ となる．この6 ml 水平に 保った径 $60 \mathrm{~mm} の$ petri dish (FalconCo) に流して み, 冷却後径 $3 \mathrm{~mm} の$ well b6個作 $り$ agarose plate とした，次化白程球浮遊液の作成方法であるが，人 パリン加末梢血 $20 \mathrm{ml}$ に Hanks' BSS 加 $6 \%$ Dext$\operatorname{ran}$ 溶液を $9 ： 1$ の割で加え, よく混和した上 $37^{\circ} \mathrm{C}$ の incubator にて15 45分間静置後白血球を含む 上層をとり Hanks' BSS にて 2000 r.p.m. 10分間 遠沈し，3回洗浄した。さらに得られた白血球を PVP $1.8 \%$ ，ヘパリン $10 \mathrm{u} / \mathrm{ml}$ 加-Eagle medium k 再浮遊し，最終的に $0,2 \times 10^{6}$ 個/ $\mu 1$ の細胞密度を有 する紐胞浮遊液を作製した．抗原の作製は腫湯塊を 準無菌的に採取し，細切後リン酸纊衝液を加えホモ ジネートした。.とれを超音波処理 $300 \mathrm{~mA} 5$ 分間行っ た後 $3000 \mathrm{r}$. p.m. 30分間遠沈し, 上清を抗原含有液 として使用した，実施にあたっては前述の白血球浮 遊夜をそれそれ $100 \mu 1$ つつ 2 本の小試験にとり，そ の 1 つに抗原液を蛋白量にして $1 \mathrm{mg} / \mathrm{ml}$ 濃毁となる ように加え，他の 1 本を抗原非添加 Controlとし， $37^{\circ} \mathrm{C}$ incubator にて60分間反応させた後，その $10 \mu 1$ を agarose plateの well に注入した。 その後 $37^{\circ} \mathrm{C}$ $\mathrm{CO}_{2}$ incubator にて18時間静置した。これをメタ， 一ルで20分間，さらに40\%ホルマリンで24時䦭固定 し, petri dishより agaroseを除去した後 petri dish 底面に遊走固定された白血球を May-Grünwald -Giemsaにて染色した。拡大鏡で遊走面積を測定し 次式により migration index(M.I.) を求めた。

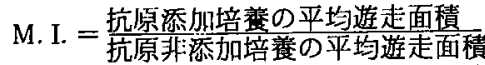

判定基準は M. I. 0.80 以下を陽性とし，0.81以上を 陰性とした，图一2にその概略を示す。

第 4 項 末梢りンパ球数

末梢白血球数に May-Giemsa染色によるリンパ 球の比率をかけたものを末梢リンパ球数とした。

\section{第 3章 成績}

第 1 節 リンパ球奻若化反応.
図 2 寒天平板法によるLMIT

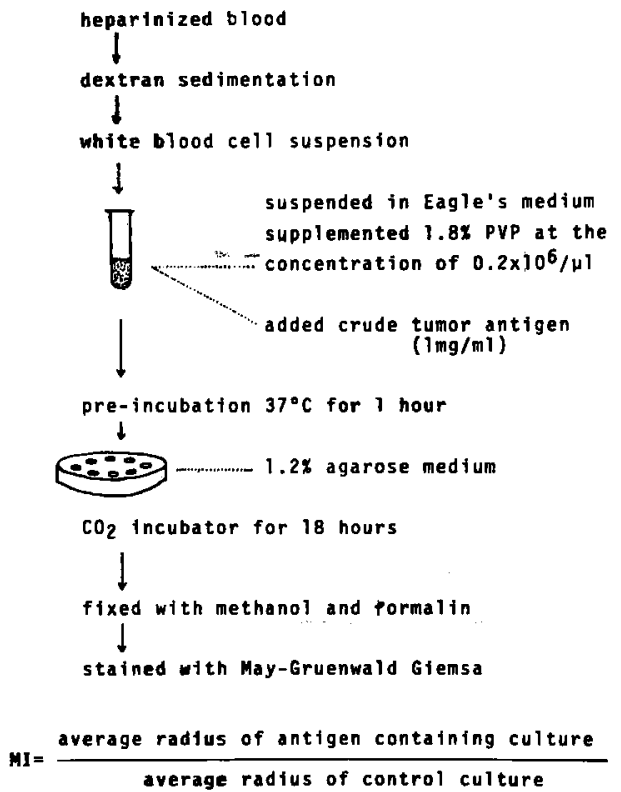

図 3 幼若化反応における至適血液量と至適 PHA-P量の検討

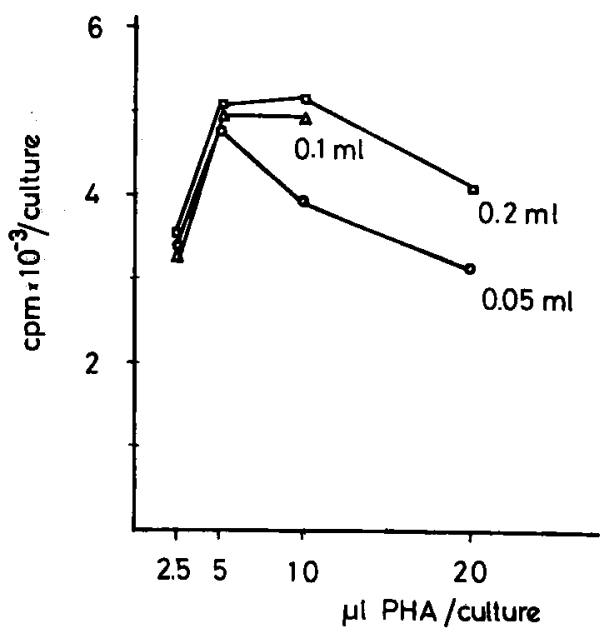

第 1 項 測定条件，測定精度ならびに正常值に関 する検討。

まず種々の測定条件を設定し至適条件について検 討した。血液量を $0.05,0.1,0.2 \mathrm{ml}$ とし, incubation 時間を 4 日間, ${ }^{125} \mathrm{I}$-deoxyuridine $0.5 \mu \mathrm{Ci}$ ，その接 
図4 幼若化反応における至適培責時間の検 討

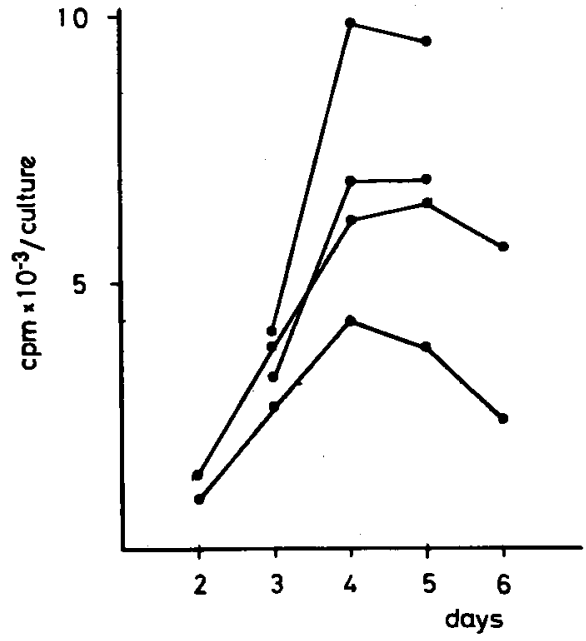

触時間を 6 時間とした時, PHA-P量 2，5，5，

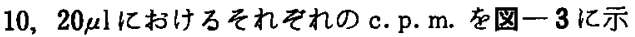
したが, PHA-P $5 \mu 1$ で高值を示し PHA-P量が多 くなるに従って c.p.m. が低下した. incubation 時 間は健康人 4 例について血液量 $0.05 \mathrm{ml}$, PHA-P $5 \mu \mathrm{l},{ }^{125} \mathrm{I}$-deoxyuridine $0.5 \mu \mathrm{Ci}$, その接触時間を 6 時間とした時，图一 4 のてとく 4 日間において高值 を示した. ${ }^{125}$ I-deoxyuridine 量とその接触時間は $0.5,1.0 \mu \mathrm{Ci}$ 亿つて血夜量 $0.05 \mathrm{ml}$, incubation 4 日間とし，それぞれ 4，6，10時間で検討したがと 6に6時間で c. p. m. の高値を示し10時間との差は 少なかった．従って血液量 $0.05 \mathrm{ml}, \mathrm{PHA}-\mathrm{P}$ 量 $5 \mu \mathrm{l}$, incubation 時間 4 日間, ${ }^{125} \mathrm{I}$-deoxyuridine 添加量 $0.5 \mu \mathrm{Ci}$ ，接触時間 6 時間という条件で比較的安定し た成績を得たので以後ての方法で測定した。

次にての方法による測定精度を検討した。すすなわ 53人の健康男子について 7 回加ら9 回くり返し採 血し，その変異係数を検討した結果表一1のでとく その值は8.5〜19.1\%であった. 続いて triplicate で 測定された235検体の S. I. についてそれそれれの変異 係数の分布をみると，表一 2 のでとく14.9\%以下の ものが73.7\%占め比較的再現性のよいものと思わ れた.ついで加令による検討のため年令を40歳以下， 40 60歳, 61歳以上の 3群にわけて比較した.表一3 のでとく加命とともに減少㑯向を認めたが，てれら 全症例の平均值を算出し $27.7 \pm 5.9$ を煡康人のS. I.
表 1 奻若化反応の再現性 一経時的則定におけ万変異係数一

\begin{tabular}{c|c|c}
\hline \hline doner & determination & $\begin{array}{c}\text { coefficients } \\
\text { of variation }\end{array}$ \\
\hline A & 9 times & $14.4 \%$ \\
B & 8 & 19.1 \\
C & 7 & 8.5 \\
\hline
\end{tabular}

表 2 幼若化反応の再現性

一triplicate samples におけろ変異係数一

\begin{tabular}{c|c|c}
\hline \hline $\begin{array}{c}\text { coefficients } \\
\text { of variation }\end{array}$ & $\begin{array}{c}\text { No. of } \\
\text { experiments }\end{array}$ & $\%$ \\
\hline $0 \sim 4.9$ & 73 & 30.6 \\
$5.0 \sim 9.9$ & 70 & 29.8 \\
$10.0 \sim 14.9$ & 34 & 13.3 \\
$15.0 \sim 19.9$ & 28 & 11.9 \\
$20.0 \sim 24.9$ & 19 & 8.1 \\
$25.0-$ & 11 & 4.7 \\
\hline
\end{tabular}

表 3 幼若化反応におけろ加命の影望

\begin{tabular}{c|c|c|c|c}
\hline age & $\begin{array}{c}\text { No. of } \\
\text { cases }\end{array}$ & range & mean & SD \\
\hline$\sim 40$ & 25 & $16.7 \sim 53.5$ & 34.0 & $10.6 *$ \\
$41 \sim 60$ & 15 & $15.9 \sim 43.6$ & 27.8 & 8.0 \\
$61 \sim$ & 6 & $14.5 \sim 34.0$ & 21.7 & $6.6 *$ \\
\hline \multicolumn{4}{c}{$* 0<0.05$}
\end{tabular}

とした。

第 2 項 肺癌症例の治療前のリンパ球幼若化反応 に関する成續.

まず各種悪性腫瑒について検討したが图一5のて

図 5 各種覀性腫㻛における幼若化反応

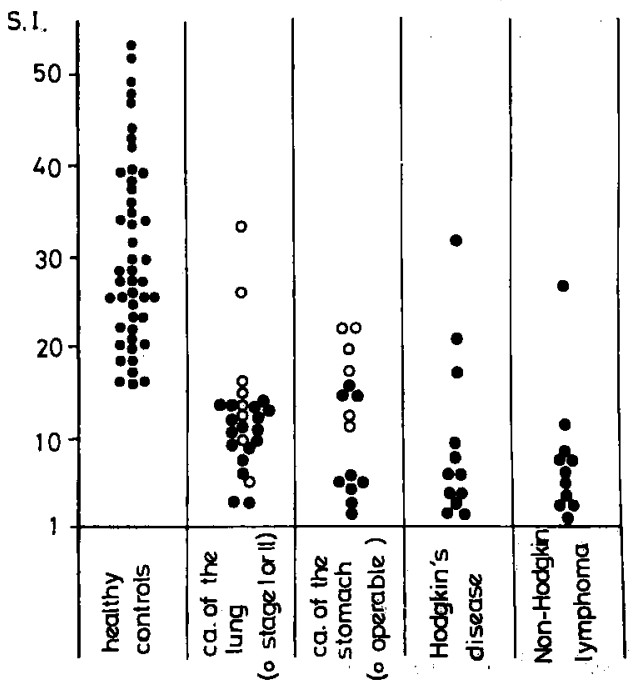


図 6 肺癌臨床病期別の幼若化反店

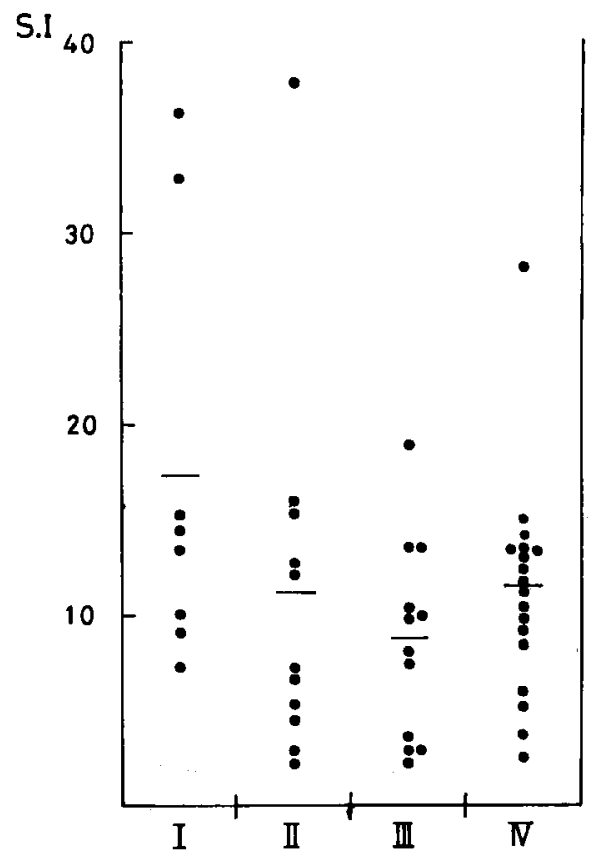

図7肺癌組織型別の幼若化反応

S.I

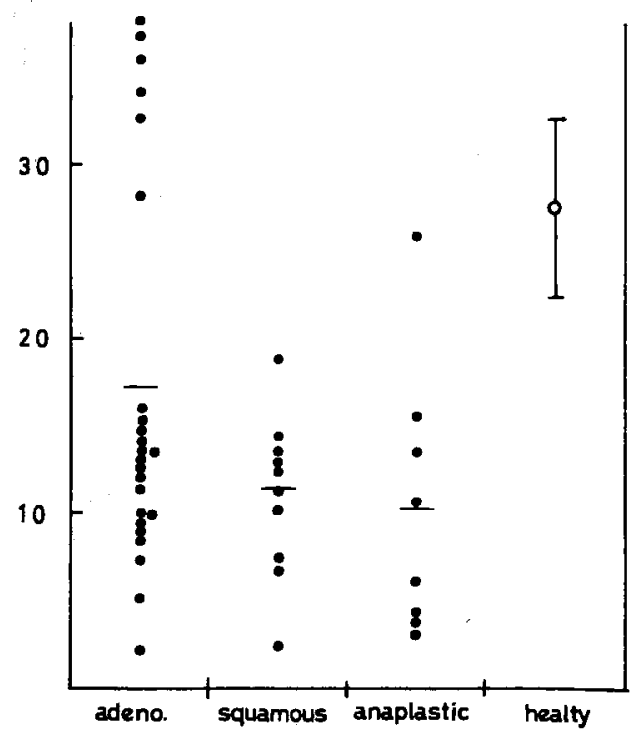

とく肺㿋, 胃癌, 悪性りンパ腫ともに健康人と比較 して低値を示した, 肺癌, 胃癌では進行癌でより低 值であるが，覀性リンパ腫ではさらにその低下は著 明であっだ.次に肺癌患者52例について臨床病期別 に分類して图一6に示した。すすなわち臨床病期別に
は I 期 8 例，II期11例，III期12例，IV期21例で，そ れぞれ S.I.の平均值は17.4，11.1，8.6，14.5であ $\eta$ ，各病期ともに健康人 S. I. の平均值 $27.7 \pm 5.9 K$ 比べ低值を示し，病期の進行とともに低下㑯向を示 したが，IV期では若干高值を示す傾向にあった．次 に組織型が判明していろ肺癌患者42例を腺癌24例， 扁平上皮癌10例, 未分化癌 8 例に分類し, その S. I. を比較した（图一7）．S.I：の平均值はそれぞれ $17,2 ， 11.0,10.2$ であり, 健康人に比し低值を示 した.眿癌のうち 6例は健康人の平均值より高値を示 したことは注目されるが, 各組織型間に推計学的有 意差はなかった。

第 3 項 化学療法症例における S.I.の変動につ いて.

化学療法単独 6 例, OK-432 併用 15例について化 学療法効果別に縮小群（腫瘤徍 $25 \%$ 以上の縮小）, 不 変群 (腫瘤径+25\% - $25 \%$ の縮小), 増悪群（腫瘤 径 $25 \%$ 以上の増大）にわけて,それそれの S.I.の推 移を検討した．図一8のでとく縮小群では治療中一 様に S. I. が低下したが, 治療後上昇傾向が示され た. しかし治療前の S.I. まで回復する症例はなか った．OK-432 併用群，非併用群における S. I. の推 移について治療中，治療後ともに有意差は認められ なかった，不変群，増悪群では治㙩中 S. I. が一様に 低下し，治療後も上暴する例は少なく，OK-432 併 用群，非併用群における S. I. の推移に有意差は認め られなかった。

第 4 項 OK-432 単独投与におけるリンパ球幼若 化率の変動について。

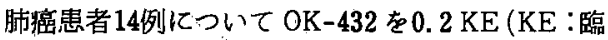
床単位) から順次増量し，原則として 1 回 $2.0 \mathrm{KE}$ 連 日投与により平均 2 週間投与した。総投与量は20

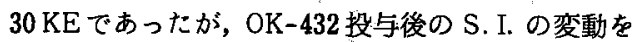
みると图一9のごくく 14 例中 8 例に上昇㑯向が示さ れたが，その程度と OK-432の投与量との間には相 関は認められなかった。これらのうち6例は明瞭な 変化として捉えられ，し加も4例は20以上と S. I.の 正常化が得られた。

第 2 節 ソベルクリン反応.

第 1 項 治療前のツベルクリン反応について.

肺癌臨床病期別では表一 4 のでとく I，II期で 28 例中 19 例 $(68 \%)$ が陽性を示し，III，IV期では37例 中23例 $(62 \%)$ が陽性を示し，病期間に特に差はな かった：全病期では65例中 42 例 $(65 \%)$ が陽性であ った．組織学的分類では表ー5のでとく有意差は認 


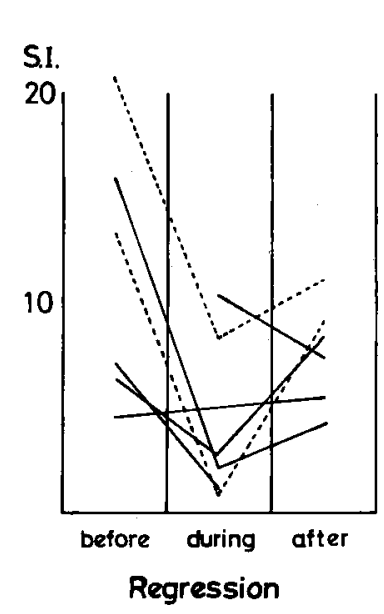

図 9 肺癌症例におけろ リンパ球幼若化率の変動

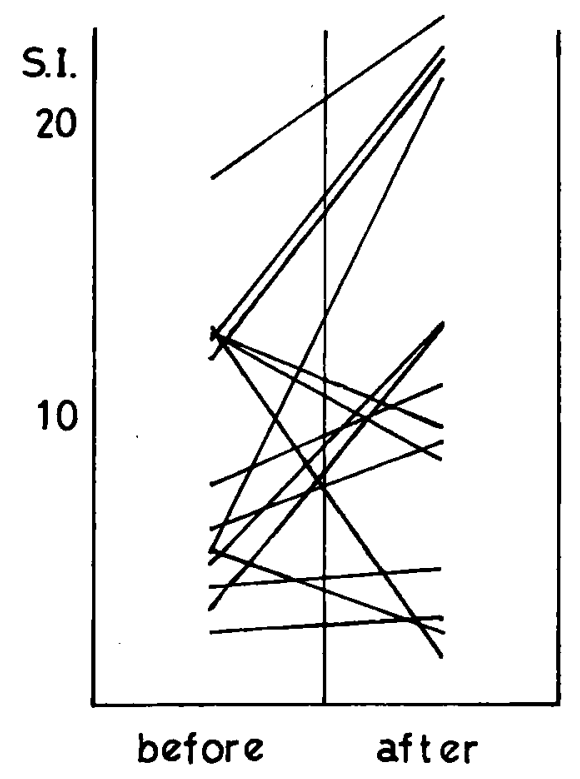

められなかった。

第 2 項 化学療法による変動, 主として OK-432 併用，非併用の比較.

次に化学療法症例について OK-432 併用群, 非併 用群の 2 群についてその推移を比較し, OK-432の

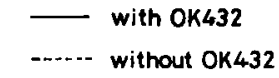

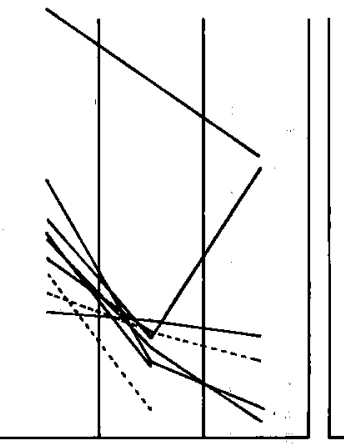

No regression

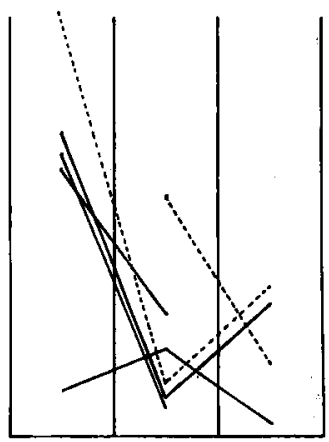

Progression
本反応に及ぼす影響を検討した.ツ反は $2 \sim 3$ 週に 1 回実施したが，治療前後の比較は原則として $1 コ ー$ スの化学療法が終了して $1 \sim 2$ 週以内(化学療法開 始後ほぼ 2 ヶ月）に行った成績を此較した，なお反 応度の推移を比較する場合，(一)または(土)が(十) 以上，(+)が(+) 以上に増強した場合，あるいは発 赤または硬結が $5 \mathrm{~mm}$ 以上増強した場合を有意の増 強とみなし，その逆の場合を娍弱，中間に位するも のを不変とした. 化学療法症例におうる OK-432 併 用症例と非併用症例の治療後のッ反の推移を一括し て表一6に示す，肺癌において OK-432 併用症例で 42例中10例にッ反の増強がみられたが，OK-432 非 併用症例18例の中には堌強例はなく両群の間に有意 差が示された。

第 3 節 末梢リンパ球数.

目一10のでとく臨床病期別にわけるど 期の cmm あたりの絶対数は平均1940，II期1730，III期1590， V 期1770であり，組織型別にわけると腺渡 1900, 扁 平上皮癌 1570 , 未分化癌 1650 で臨床病期，各組織型 の間に有意差を認め得なかった。

第 4 節 肺癌患者におけるリンパ球幼若化反応, ッベルクリン反応, 末梢リンパ球数の相互 関係ならびにてれらの総括評価について 炊に幼若化反応とッ反，幼若化反応と末梢リンパ 球数それそれについてその相関性を検討した結果, これらの間に特に密な相関を諗めなかったが，とれ ら三者の成績を総合して評価する方法を試み臨床病 期, 生存期間との関係者検討した。すななら表一7 


\begin{tabular}{|c|c|c|c|c|c|c|}
\hline \multicolumn{7}{|l|}{ 表 4} \\
\hline \multirow{2}{*}{\multicolumn{2}{|c|}{$\begin{array}{l}\text { clinical } \\
\text { stage }\end{array}$}} & \multirow{2}{*}{$\begin{array}{l}\text { No.of } \\
\text { cases }\end{array}$} & \multirow{2}{*}{$\begin{array}{l}\frac{-}{\text { No.of }} \\
\text { cases }\end{array}$} & \multirow{2}{*}{$\frac{ \pm}{\%}$} & \multirow{2}{*}{$\frac{t}{\text { No.of }}-$} & \multirow{2}{*}{$\frac{\#}{\%}$} \\
\hline & & & & & & \\
\hline I & II & 28 & 9 & 32 & 19 & 68 \\
\hline III & IV & 37 & 14 & 38 & 23 & 62 \\
\hline
\end{tabular}

表 5 肺癌組織型別のツベル゙クリン反応

\begin{tabular}{|c|c|c|c|}
\hline & no. of cases & $\begin{array}{c}\text { no. of } \\
\text { positive cases }\end{array}$ & $\%$ positive \\
\hline Adenocarcinoma & 16 & 10 & $63 \%$ \\
\hline Squamous cell ca & 11 & 7 & 67 \\
\hline Anaplastic ca. & 8 & 5 & 63 \\
\hline $\begin{array}{l}\text { Malignant } \\
\text { lymphoma }\end{array}$ & 30 & 8 & 27 \\
\hline
\end{tabular}

表 6 肺癌化学療法症例の OK-432併用群, 非併用群におけるッベルクリン反応の変動.

\begin{tabular}{|c|c|c|c|c|c|c|c|c|}
\hline \multirow{3}{*}{$\begin{array}{l}\text { response } \\
\text { to } \mathrm{C} . \mathrm{T} \text {. }\end{array}$} & \multicolumn{4}{|c|}{ with $\mathrm{OK}-432$} & \multicolumn{4}{|c|}{ without $\mathrm{OK}-432$} \\
\hline & \multirow{2}{*}{$\begin{array}{l}\text { no. of } \\
\text { cases }\end{array}$} & \multicolumn{3}{|c|}{ PPD skin test } & \multirow{2}{*}{$\begin{array}{l}\text { no. of } \\
\text { cases }\end{array}$} & \multicolumn{3}{|c|}{ PPD skin test } \\
\hline & & 1 & $\rightarrow$ & $\downarrow$ & & $\uparrow$ & $\rightarrow$ & $\downarrow$ \\
\hline $\begin{array}{c}\text { very } \\
\text { effective }\end{array}$ & 3 & 1 & 2 & 0 & 1 & 0 & 1 & 0 \\
\hline effective & 14 & 3 & 7 & 4 & 6 & 0 & 5 & 1 \\
\hline ineffective & 25 & 6 & 13 & 6 & 11 & 0 & 7 & 4 \\
\hline total & 42 & 10 & 22 & 10 & 18 & 0 & 13 & 5 \\
\hline
\end{tabular}

表 7 肺癌症例におけるリンパ球幼若化反応, ッベルクリン反応，末佾リンパ球数の総 合評価と臨床病期の相関。

図10 肺癌臨床病期別の末梢りンパ球数

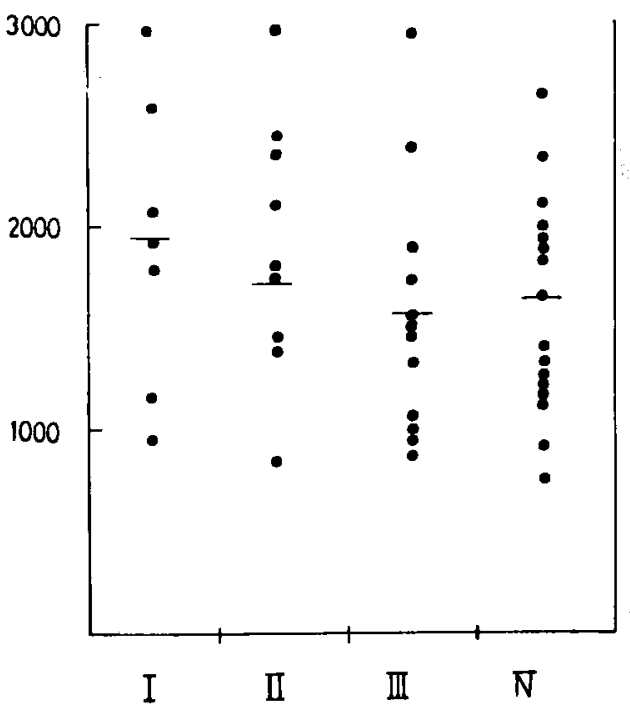

\begin{tabular}{|c|c|c|c|c|}
\hline stage & I & II & III & IV \\
\hline excellent & 1 & & & \\
\hline good & 5 & 2 & 2 & 4 \\
\hline fair & & 5 & 8 & 7 \\
\hline poor & & & 1 & 1 \\
\hline
\end{tabular}

excellent: All of PPD. PHA test and peripheral lymphocytes count are within nomal

good : Two of them are within nomal

fair : One of them is within nomal

poor : None of them is within nomal

表 8 肺澺症例におけろリンパ球幼若化反忘, ツベルクリン反応，末梢リンパ球数の総 合評価と早期死亡例の生存期間.

\begin{tabular}{l|c|c|c|c|c}
\hline \hline survival & 1 Month & $2 \mathrm{M}$ & $3 \mathrm{M}$ & $4 \mathrm{M}$ & $5 \mathrm{M}-$ \\
\hline Excellent & & & & & \\
\hline good & & & 1 & 1 & 1 \\
\hline Fair & 2 & 2 & 2 & 1 & 1 \\
\hline Poor & 2 & & & 1 & 1 \\
\hline
\end{tabular}

のでとく評価の基準をさだめ, 各症例を excellent, good, fair, poor 亿区分して臨床病期と対比此する と, I, II期では excellent, good が多くIII, IV 期 
表 9 LMITにおける至適抗原量の検討。 concentratjon of antigen

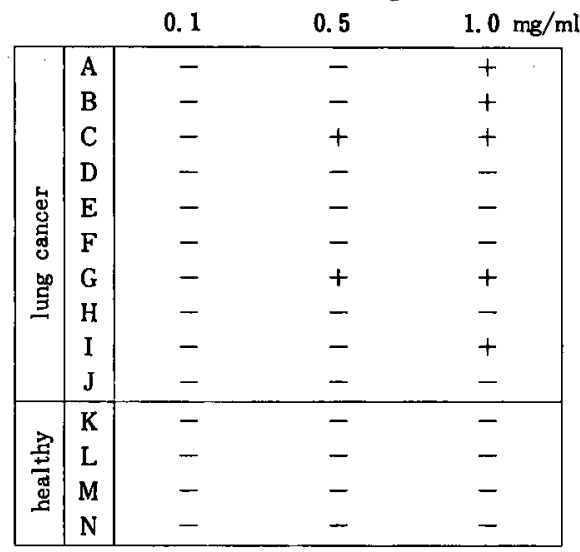

表10ＬM ITの再現性

一経時的測定におけ万変異保数一

\begin{tabular}{c|c|c}
\hline \hline doner & determination & $\begin{array}{c}\text { coefficients } \\
\text { of variation }\end{array}$ \\
\hline A & 5 times & 1.57 \\
B & 7 & 3.92 \\
C & 5 & 3.59 \\
\hline
\end{tabular}

になるに従い poor が多くなる傾向がうかがわれ総 合的評価の有用性が示された。次に III， IV 期肺涭早 期死亡例15例存期間別に前述の評価方法で検討 すると表一8のでとく全般に excellent, good は少 なく12例 $(80 \%)$ が fair ないし poor であり生存期 間との相関がみられた。

第 5 節 Leucocyte migration inhibition test

第 1 項 至適抗原漕度および再現性に関する検討 まず肺絽他家抗原の最終灙度を $0.1 \mathrm{mg} / \mathrm{ml}, 0.5$ $\mathrm{mg} / \mathrm{ml}, .1 \mathrm{mg} / \mathrm{ml}$ にわけその至適浱度を゙检討した。 同時に測定できた肺癌患者 10 例と健康人 4 例におけ ろ M. I. は表一9に示すことく肺癌においては抗原 濃度 $0.1 \mathrm{mg} / \mathrm{ml}$ では全て陰性, $0.5 \mathrm{mg} / \mathrm{ml}$ では10例中 2 例, $1 \mathrm{mg} / \mathrm{ml}$ では 5 例陽性であり，しが $0.5 \mathrm{mg}$ $/ \mathrm{ml}$ 陽性症例は $1.0 \mathrm{mg} / \mathrm{ml}$ 濃度でいずれも陽性の成 續を示した。一方健康人においてはいずれの抗原濃 度においても陰性であったので, 以後 $1 \mathrm{mg} / \mathrm{ml}$ 濃度 で検討を行なった．次に本法の再現性を検討するた め健康人 3 例について PPDを抗原として 5-7 回 くり返し測定した結果，表一10のごとくその変異倸 数は各々 $1.57 ， 3.92 ， 3.59$ と比較的高い再現性が得 られた。

図11 肺癌, 他癌, 肺感染症および健康人に おけるLMIT

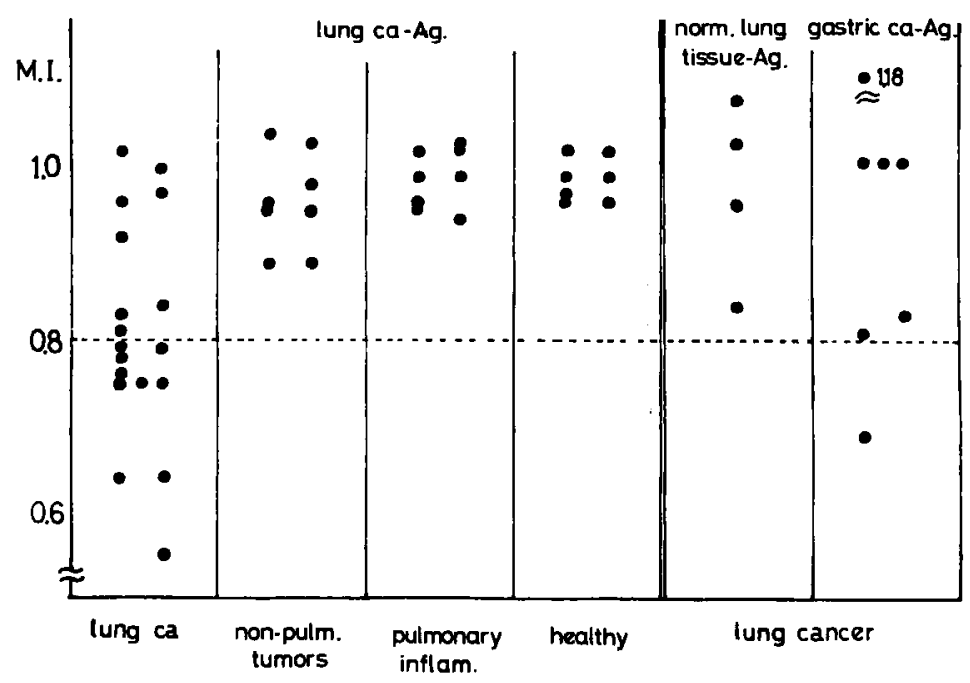


2 項 肺癌患者, 非肺癌々症例, 良性呼吸器疾 患における倹討。

肺癌患者19例について本法を施行すると図一I1の ごとく10例（53\%）か陽性を示した。症例が臨床病 期 I，II期に偏り，病期別には比較できなかった。 対照として肺㾔以外の癌症例 8 例（胃癌 3 例, 肝癌, 大腸癌, 前立腺澏, 為粘液膠腫, 原発不明癌各 1 列), 肺感染症群 8 例（帕結核 3 例, 気管支喘息, 肺炎各 2 例, 肺膿湐 1 例)，健康人 7 例について検討したが 全て陰性であった．さらに肺癌患者 4 例に正常肺組 織を抗原として検討したが全て陰性であった。同様 に胃癌抗原を用いた場合，肺癌患者 7 例中 1 例のみ が陽性であった，遊走促進と思われる症例はみられ なかった。

第 3 項 化学療法による migration index の変動 について.

次に癌化学療法（一部放射線治療）施行における M.I. の変動について検討した，図一12のてとく治 港前陽性を示した8例枱治療中全て陰性となり,治 療後の検討ができた 4 洌のうち胸部重熘陰影が縮小 した 2 例中放射線治療の 1 例は陽性を示し, 他の 1 例は陰性であった．無効 2 洌は化学㙩法後もひき続 き陰性を示した。 また化学滰法前に陰性であった 1 例は化学療法により著明な胸部腫塯陰影の縮小を得， 陽性となった，治療後完全寛解を得た 5 例は全て陰 性であったが再発を示した 1 例は陽性化した。

第 4項 OK-432 単独投与における migration index の変動について。

肺癌患者 6 例について OK-432 老 0.2KEから順次 増量し，原則として 1 回 $2.0 \mathrm{KE}$ 連日投与により平均 4 週間投与し，総与量 30 40 KEで検討した。図一 13 のごとく投与前陰性であった 3 例中 2 例は投与後 陽性化を示した。

第 6 節 肺癌化学療法症例における OK-432 投与 群，非投与群の生存期間に関する検討

肺癌症例について化学療法のみが行われた26例と， 化学潦法と OK-432 同時併用，続いて OK-432 によ ろ稚持療法が行われた 21 例の生存期間を比較したと ころ，图一14のてとくく前群の50\%生存期間 4 力月， 後群のそれは 6 カ月であったが，後群において長期 生存症例が認められたため平均生存期間にお゙いて前 群4.8力月, 後群 8.2 力月と $\mathrm{OK}-432$ 併用投与群に有 意 $(\mathrm{P}<0.05)$ の延長が認められた.
図12 肺癌症例の船療によるLMITの推移

o CRR. chemotherapy radiotherapy

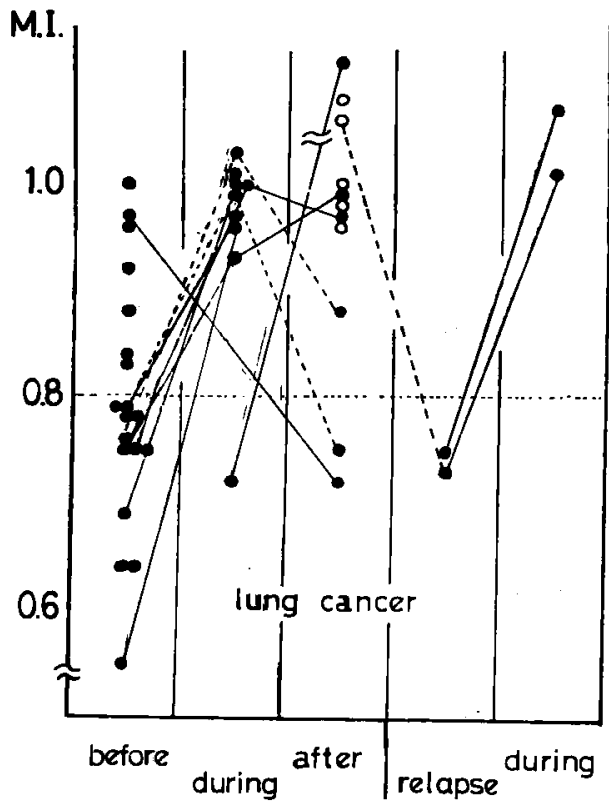

図13 肺癌症例におけろOK-432投与前後の LMITの変動

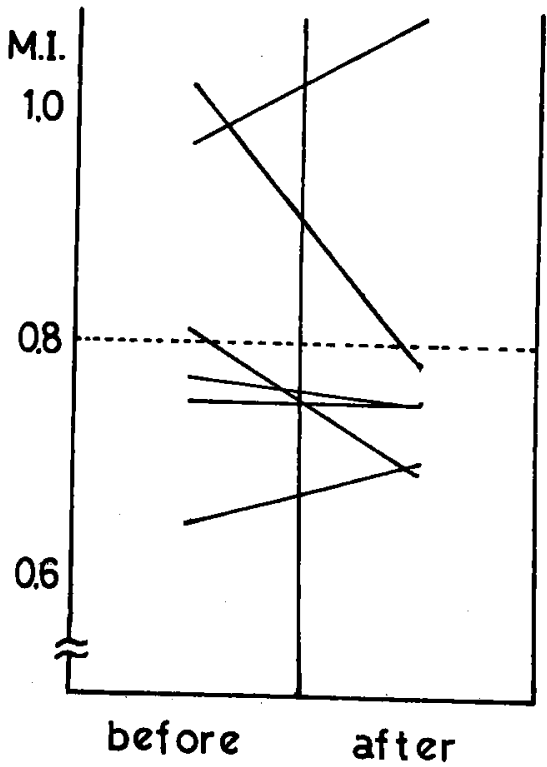


図14 肺癌化学療法症例におけるOK-432併 用群, 非併用群の生存期間

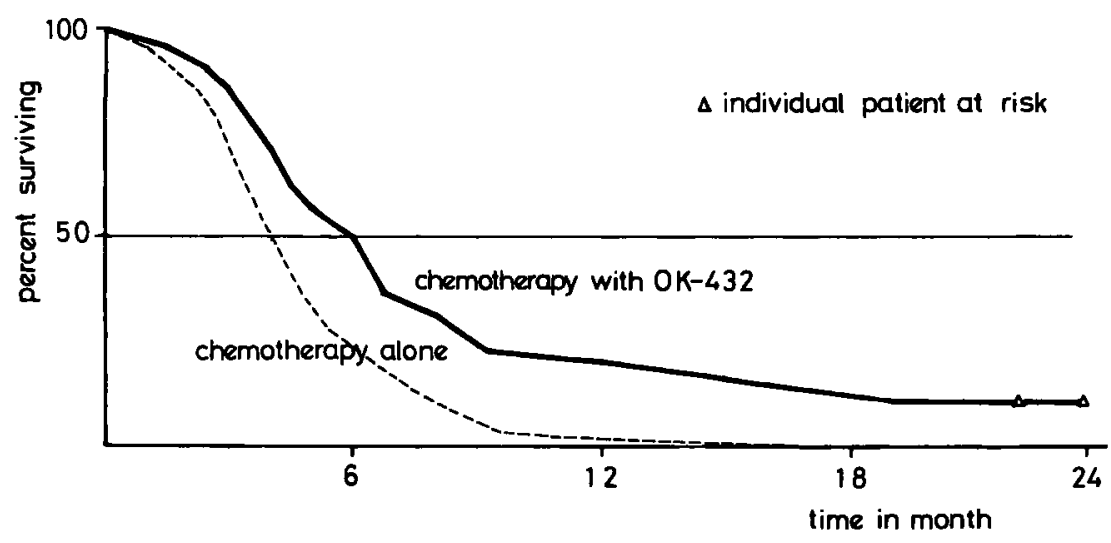

肺滨患者に出現する細胞免度異常の検討を幼若化 反応，ツ反，末梢リンパ球数，LMITをパラメータ 一として検討した. PHAによるリンパ球幼若化現象

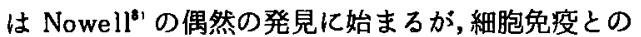
関連は Pearmain ら”によりッ反陽性者のリンパ球 を培養する際に，特異抗原であるPPD添加で幼若 化が起こることを発見したととから発展した.PHA に反応するリンパ球は T細胞であり，その PHAに対 する幼若化率が T細胞の機能を表現するといわれて いる. 幼若化反応には牙球様細胞の鏡検下での算定 法や,リンパ球を分䀶し核酸前駆物質である ${ }^{3} \mathrm{H}-$ thymidine の取り込みを計測する方法があるが，前 者はやや客観性に久け後者は煩雑である点を考虑し Pellegrinoらによる微量全血法に従った. 本法は比 較的簡便であり再現性が高いこと，全血であるため リンハパ球の絶対数と機能を総合した結果をみている 点などの特徽がある.正常状態における in vitro test と加命との関連については, Pisciotta ら ${ }^{101}$ は健康 人293例の検討から，0歳から思春期までの間は漸次 上昇するが，思春期を頂点として以後はその平均值 は加令とともに有意に低下すると述へてている．これ に対し早川|"1小肾期と壮年期との比較から年令に よる有意差は認められないと報告している，著者は 年令を三群に分けて検討した結果，加令とともに低 下順向を示し，40歳以下と61歳以上を比較した場合 高合者に明らかな低下が認められた。

癌患者は一般にリンパ球幼若化率が低いとする報

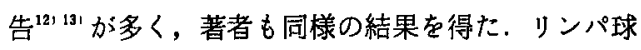

幼若化率の低下と癌の進展度は並行するとする報告 が多〈' ${ }^{1415 !}$ 著者による肺患患者についての臨床病期 別の検討においてもはほ同様の成續が得られている. 臨床病期 I 期において既に多くの症例が低值を示し ており，胸部異常陰影を示す他の良性疾患との鑑別 診断的意義を示唆するが, さらに検討される必要が あろう.しかしIV期において比較的高值をとる例が あり，これらは原発腫瘤が小さくかつ遠隔転移病柴 も限局し，全身状態む良好であったととから，PHA に対するリンパ球の幼若化は臨床病期よりもむしろ 宿主の担う総腫湯量と並行するのではないかとも考 えられる，一方組織型別分類での検討では各組織型 に特に有意差はみられず, Barnesら ${ }^{161}$ の肺癌患者 についての報告と一致する成續であった。

癌患者における非特異的免疫能の低下の背景には T細胞の減少ならびにその機能低下が存在すること はほば一致した見解であるが，血清内には免疫抑制 的に㗢く種々の因子があり，幼若化反応の評価に影 響を与えている可能性がある. 現在 $\alpha$-globulin と の関連性,腫湯抗原あるいはそれと抗体との immune complex の存在, toxohormone 樣因子の存在などが 報告されており考虑すべきととと思われる!! 18

次に化学療法によるリンパ球幼若化率の推移につ いて検討したが，化学療法中は一椂に低下し，抗癌 剂のリンパ球抑制作用が考えられた．古くから抗癌 剤の使用により網内系機能の著明な低下を来たし， 腫煬が逆に増大するとする adverse effect ${ }^{191}$ が指摘 され, 副腎皮質木ルモン, azathioprine, L-aspa- 
raginase,"1 neocarzinostatin,"11 cyclophosphamide，などそのリンパ球抑制作用が見い出されたか， これら以外の抗癌剤についても類似の作用機序が考 えられる.リンパ球幼若化率は化学療法後も睡瘍縮 小群で軽度の改善が得られたが，化学療法前の值ま たは正常值にまで回復する例はなかった．悪性リン パ腫の完全寛解例の多くでは化学療法後はとんど正 常值にまで改善されており 吕!肺癌において改善の悪 いのは悪性リンパ腫に比べ化学療法剂の総投与量が 多く，加えて要性リンパ腫に匹敵する化学療法効果 が得られないととに起因するものと思われる。

ッ反は細胞免度能のパラメーターの代表として常 用され，癌患者にその反応能力の障害はないとする ものもあるが，多くは低下するとし，進展度との相 関が認められていろ. Brugarolas ら ${ }^{23}$ は肺癌108例 を limited, widespreadに分類し，後者の陽性率の 低下を示しているが，著者は肺癌を臨床病期 I，II 期と III， V 期に分類して検討した結果，陽性率 $68 \%$ ， 62\%と推計学的有意差はなく，乙れには年令分布の 不均一性が関与している様に思われた。全病期では 陽性率65\%であり，他に報告されている悪性腫韵症 例の陽性率に比べ幾分高值であっだ21251 細胞免疫能 低下の典型的な疾患である覀性リンパ腫では陽性率 が低く，教空の悪性リンパ腫30例では陽性率27\%を 示し，肺癌患者とは明らかな相違を示した。

末梢リンパ球数について白神ら ${ }^{261}$ は進行癌ことに 転移癌や末期癌では症例の過半数にリンパ球减少を みているが，著者の肺癌における検討では病期との 相関はなかった。また末梢りンパ球数と幼若化反応， あるいはツ反との間にも相関を認めず,これはリンパ 球の絶対数よりもむしろその機能が重要であること を示すものであろう，同様に幼若化反応とッ反の間 にも相関はなく，後者の反応にはリンパ球のみなら ず多核白血球，マクロファージ, 形質細胞など種々 の遊走細胞や多くの化学物質が関与していることが 考えられ当然のことかも知れない.そこで糼若化反 応, ッ反，末梢リンパ球数の三者を用いて病期との 相関をみた結果進展度と関連性がうかがわれ，種々 の複雑な因子の関与する担癌生体の細胞免度能の护 握にはさらにT, B細胞 subpopulation, DNCB 皮 内反応，PHA皮内反応などのパラメーターを加えた より総合的な検討が必要であろうと考えられた。

LMITは歴史的にはマクロファージ遊走阻止試験 から発展したものである。まず Rich and Lewis ${ }^{271}$ がッ反陽性動物のリン，䖪繶片とPPDを同時に培養
すると組織片からの細胞の遊走が阻止されるととを 発見し, 続いて George and Vaughan ${ }^{281}$ がBCG感 作モルモットの腹腔細胞をガラス毛細管に詰めて小 型シャーレ内で PPDと培養すると毛細管からの腹腔 細胞の遊走が著明に抑制されることを証明するとと により,遅延型アレルギー反応の in vitroにおける 定量化が可能になうた.次いで David,' Bloom and Bennett ${ }^{301}$ がこの現象は感作リンパ球が特異抗原と 反応の結果 migration inhibitory factor(MIF) を 産生し, マクロファーシの遊走を抑制するためであ ることを見い出した. LMITは S $\phi$ borg and Bendixen ${ }^{31}$ か' indicator cell として多核白血球を用い 末梢リンパ球と一緒にガラス毛細管につめて特異抗 原と培養すると毛細管からの遊走が抑制されること を証明し，本法も遅延型アレルギーを反映すると報 告して以来, 細胞免疫の検索に応用されてきた。 Clausen'21 は Carpenter ら ${ }^{331} の$ agar gel 法を応 用し, ッ反陽性の人白血球を PPDとともに agarose plate 中に入れて培養すると遊走が抑制されること を証明し，ての方法も遅延型アレルギーを反映する とした。さらにAxらはこれに改良を加え；癌患者 白血球と Soluble antigen 用いて消化器癌, 乳 癌, 肺癌など担㴼生体の細胞免疫能の証明を試みた。 本法は従来の毛細管法に比較して採血量と抗原量が 少なくてすみ,リンパ球と indicator cell である多 核白血球が同一個体から得られる点, 手技が簡便で 遊走野の境界が鮮明である点, 再現性が高い点など の特徴がある。

著者は肺䄆患者に応用し，多くの報告者のでとく M. I. 0.80以下を陽性とすると $53 \%$ の陽性率を得た。 しかし他家由来の抗原を用いているため，乙の陽性 の評価は腫煌共通抗原の存在を示したものであると 思われる．また抗原が粗であるため対照として白血 球側では他癌群, 肺感染症群, 健康人で検討し, 抗 原側では正常肺組艊抗原, 胃癌抗原を用いて検討し た。その多くは陰性であったが，胃癌抗原を用いた 肺癌 1 例に陽性を認め, 器器間の共通抗原の存在も 示唆する結果を得た. 症例が臨床病期 I, II期に倔っ たため臨床病期別の桧討ができなかったが，悪性黒 色腫における $\mathrm{McCoy} ら^{301}$ の報告のごとく早期癌陽 性率が高いととが考えられ，たとえ共通抗原であっ ても臨床上早期発見に役立つもの之思われる。

この LMITに関し今回の検討では抗原が粗である にもかかわらず対照は全て陰性であったが, formalin 処理法, $3 \mathrm{~mol} \mathrm{KCl}$ ⿸用いろ方法,'過塩素酸抽 
出物による方法などさらに純代した抗原の精製によ ろ検討が必要になるであろう。また本成啧には血清

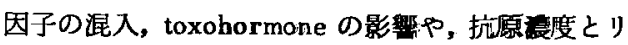
ンパ球の感作の程度に上り抑制, 促進 ${ }^{36}$ の二重の結 果が得られることが考えられ，LMITが逮延型アレ ルギーを反映するとするには慎重を要すことであろう. 次に治療との関保では治療前陽性:であった症例は 治療後全て陰性となす，ての間癌の進展が著明にみ られていないととから抗癌剤, 放射線治療の影響か～ 考元られた. Wahl ら $ら^{3 n}$ は glucocorticosteroid が MIF の産生阻害に作用すると述へているが， LMIT においても MIF と分子量の異った leucocyte inhibitory factor (LIF) ${ }^{\text {su }}$ に対して類似の作用機序でり ンパ球阻害に㗢いたもの之考觉られる。治療後腫瘤 陰影の縮小ととも院泩化した例, 治療中にもかか わらず陽性例，完全寬解後再発とともに陽性化した 例などを考充合わせると，LMTT陽性は至適抗原の

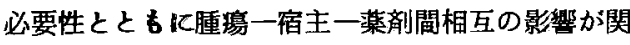
係しているるのと思われた。

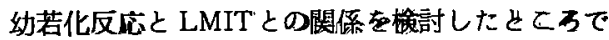

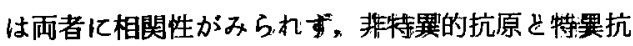
原の認知する部分が異なっているとの報告 ${ }^{3901}$ 免疫 不全症の一型で両者に睤離があるとの報告等どをみ ろと，両者間泪相関性が示されるかったことは当然 のととと思われむしろそのために担癌生体の細胞 免疫能の把握にいくつかのパラメーターによろ総合 的な評価が必要であろうと考えられた。

溶連菌剤 OK-432 の抗腫場効果については木村ら

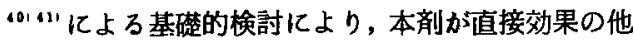
亿宿主を介する作用を有することが報告されている． それ故本剛を臨床における免度化学寮法のスケジュ 一ルの中で用いた場合の有用性について幼若化反応， ッ反，LMITのパラメーターを用いて検討した．化 学療法に OK-432 併用した群と非併用群を幼若化 反応で比較したとてろ，化学裳法前後におけるリン パ球幼若化率の推移は臨床経過にかかわらず有意差 は認められなかった.しかし OK-432 単独投与前後 におけるリンパ球幼若化率の変動で明らかな上昇が 得られたてと, ッ反で有意の差をもって本䇕併用群 に反応の増強が認められたてとは, 複雑な担癌宿主 免没機構の中で一部のパラメーターの改善を示した にすきないにしても，動物実験レベルだけでなく人 癌にわいても本郕が非特異的免疫能の賦活に関与し ているてとをうかがうととができた，さらに本郕単 独投与例における LMITで投与前除性例が投与後陽
性化したてとは，本㓮の癌抗原認織にるける adju一 vant 䴔果を示声作用のあることが示陖された。従っ

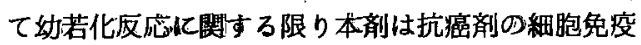
能低下に対する防此作用は少はいが，腫場が縮小し 細胞数の减少した時点では肺澏患者の病態の改善の

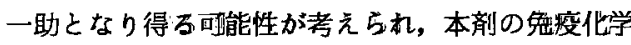
療法としての意垺があるものと思われた．実際末期 肺癌III, IV 期の症列で本剂併用化学療法群之化学療 法のみの群とを比較して生存期間の検討を行ったよ てろ, 前者澺历有合効果が示され， $50 \%$ 生存期 間の延長および長期延命症例に上る平均生存期間の 延長が示された，すなわち免疫療法郕としての OK一 432 の併用維持療法が延命に対して有利であること 加明らかとなった。個々の症例についてみると，寬 解導入療法後本剂を主体として維持療法を行った末 期肺稳患者で 2 年以上経過した症例が 4 例あり。こ 九らは完全寛解に近い状態で，中には OK-432 投与 のみで過きている症例もあり，正常人と全く変ら如 勤務をしているものもあるととは特筆すべきてとて あろう。またかかろ症例においてはリンパ球约若化

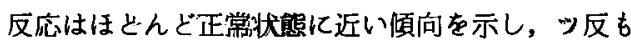

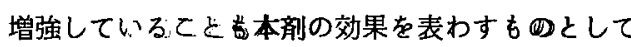
興味深い。

\section{第 6 章 結 諭}

肺癌患者䎲おいてその細胞性免疫能の検討のため 幼若化反庞， ツ反，末梢リンパ球数，LMIT をパラ メーターとして用いいくつかの新知見を得，さらに

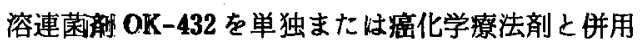
しその有用性を認めた。すなわち，

1）奻若化反応では肺癌症例は健康人に比へ低值を 示し, 臨床病期分類でも病期が進展するに伴い低下 傾向にあった，化学療法後も多くは低值であった。 OK-432併用群, 非併用群における比較でも有意差 は認められなかっった。

2）ッ反汉では陽性率が比較的高值であったが，病期 とは相関がなく，末梢リンパ球数においても同様で あっだ

3）てれら三者すなわち幼若化反応，ツ反，末梢リ ンパ球数を総合的に検討すると病期との相関が認め られた。

4） LMITでは陽性が約半数にみられ，腫場共通抗 原の存在が考えられた。ささらに化学療法による検討 を加えた結果, LMITの評価には腫湯一缩主一薬成 相互の影響を考慮するととが重要であると思われた。 
6) 溶連菌猎 OK-432 癌化学療法に併用した群と 非併用群とを比較すると, 前者にツ反の有意の増強 が得られ，また OK-432 単独投与例においてリンパ 球幼若化率の上昇, LMITの陽性化がみられ, 肺澏 に対し本剂の免疫賦活剂としての有用性が示された。 7) 末期肺癌患者症例におけろ OK-432 併用化学療 法群は非併用群に比へ $\mathbf{5 0 \%}$ 生存期間，平均生存期間 の延長が示された。
稿を終るにあたり御指導御校閲を賜った恩帥平木 絜教授に深甚の謝意を表わすとともに，御賏篤なる 御指導を賜った木村郁郎講帥に深謝し, 終始御助言 御鞭達をいただいた大㚜泰亮講師に感謝の意を表し ます。

なお本論文の要旨は第16回日本肺癌学会総会 (昭 和 50 年大阪) ならびに第23回日本化学療法学会西 日本支部総会 (昭和50年長崎)において発表した。

\section{文献}

1) Stern, K.: Investigations on the reticuloendothelial function of cancer patients. J. Lab. Clin. Med., 26:809-817, 1941 .

2）山形敞一, 三浦清美, 宇塚善郎, 宮森昭郎, 金子昭雄, 杉内㟨, 小野田重敏, 亘場利雄, 菊田豊：内科疾 患における網内系機能. 最新医学, 17：1119-1132, 1962.

3) Foley, E. J.: Antigenic properties of methy lcholanthrene-induced tumors in mice off the strain of origin. Cancer Res., 13:835-837, 1953.

4 ) Eilber, F. R. and Morton, D. L. : Impaired immunologic reactivity and vecurrenee frollowing cancer surgery. Cancer, 25:362-367, 1970.

5) Pellegrino, M. A., Ferrone, S., Pellegrino, A. and Reisfeld, R. A. : Arapid microtechnique for in vitro stimulation of human lymphocytes by phytohemagglutinin. clin. Immunol. Immunopathol., $2: 67-73,1973$.

6) Clausen, J.E.: Tuberculin-induced migration inhibition of human peripheral leucocytes in agarose medium Acta. Allergol., 26:56-80, 1971.

7) Ax, W. and Tautz, chr.: Assay of leucocyte migration inhibition under agarose. Behring. Inst. Mitt., $54: 72-80,1974$.

8) Nowell, P.C.: Phytohemagglutinin: an initiator of initosis in cultures of normal human leucocytes. Cancer Res., 20:462-466, 1960

9) Pearmain, G., Lycette, R. R. and Fitzge,rald, P.H.: Tuberculin-induced mitosis in peripheral blood leucocytes. Lancet, $1: 69 ;-630,1963$.

10) Pisciotta, A.V., Westring, D. W. and Deprey, C.: mitoge ${ }^{\text {nic }}$ effect of phytohaemagglutinin at different ages. Nature, 215 : 193-194, 1967.

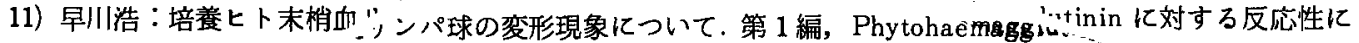
ついて.アレルギ., 17:188-209, 1968.

12) Garrioch. 5. B., Good, R. A. and Gatti, R. A.: Lymphocyte response to phytohemagglutinin in patir ints with non-lymphoid tumors. Lancet, I:618, 1970.

13) Harris, J., Bagai, R. and Stewart, T.: Immunocompetence and response to antitumor treatment. New Engl. J. Med., 286:494, 1972.

14) Thomas, J. W., Coy, P., Lewis, H. S. and. Yuen, A. : Effect of therapeutic irradiation on lymphocyte transformation in lung cancer. Cancer, $27: 1046-1050,1971$

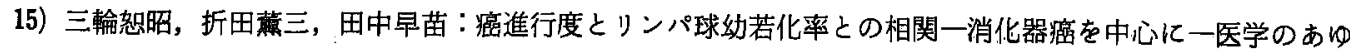
み, $80: 634-635,1972$.

16) Barnes, E. W., Farmer, A., Penhale, W. J., Irvine, W.J., Roscoe, P., and Horne, N. W.: 
Phytohemagglutinin-induced lymphocyte transformation in newly presenting patients with primary carcinoma of the lung.: Cancer, 36:187-193, 1975.

17) Sample, W.F., Gertner, HR. Jr. and Chretien, PB.: Inhibition of phytohemagglutinin-induced in vitro lymphocyte transformation by serum from patients with carcinoma. J. Nat. Cancer Inst., $46: 1291-1297,1971$.

18) Sjögren, H. O., Hellström, I., Bansal, S. C. and Hellström, K. E. : Suggestive evidence that the "blocking antibodies" of tumor-bearing individuals may be antigen-antibody complexes.

Proc. Nat. Acad. Sci., $68: 1372-1375,1971$.

19) Kondo, T. and Tsukui, K.: Effect of nitrogen mustard. N-oxide, X-rays, and cortisone on Yoshida sarcoma metastasis developement. Proc. Soc. Exper. Biol. Med., $102: 384-386,1959$.

20) McElwain, T.J. and Hayward, S. K.: L-asparaginase and blastogenesis. Lancet, $1: 527$, 1969.

21）横幕省三, 小林政英, 若山喜久子, 今井邦之, 大野竜三, 山田一正：NCSのヒトリンパ球 PHA反応性 blas togenesis に及ほす影響, 医学のあゆみ, $93: 19-20,1975$.

22）占部康雄, 大叒泰亮, 安原尚蔵, 杉山元治, 藤井昌史, 町田健一, 木村郁郎：各種覀性腫湯化学療法症例 におけろ細胞性免疫能の推移一主に PHA-test を指標として一第13回日本癌治療学会総会抄録集, 185 , 1975.

23) Brugarolas, A. and Takita, H.: Immunologic status in lung cancer. Chest, 64:427-430, 1973.

24）三輪怒昭, 小川潔, 金田象䫓, 国米昭欣, 折田薰三, 田中早苗：リンパ球幼若化率, ッベルクリン反応, D N C B 反応に上万癌進行度の判定. 日癌治療会誌, $8: 68-69,1973$.

25) Solowey, A. and Rapaport, F. T.: Immunologic responses in cancer patients. Surg. Gynec. Obstet., $121: 756-760,1965$.

26）白神婂, 岩尾害人, 今川太仁, 橋詰博仁, 小浜貴良, 久次米隆司, 涉谷和彦: 担癌症の末梢リンパ球. 最 新医学, $24: 1664-1671,1969$.

27) Rich, A. R. and Lewis, M. R. : The nature of allergy in tuberculosis as vevealed by tissue culture studies. Bull. Johns Hopkions Hosp., $50: 115-131,1932$.

28) George, M. and Vaughan, J.H.: In vitro cell migration as a model for delayed hypersensitivity. Proc. Soc. Exp. Bicl. Med., 3:514-521, 1962.

29) David, J.R.: Delayed hypersensitivity in ${ }_{i i}^{2}{ }^{2}$ : its mediation by cell-free substances formed lymphoid cell-antigen interaction. Fvoc. Nàt. Acad. Sci., 56:72-77, 1966.

30) Bloom, B. R. and Bennett, B.: Mechanism of a vacion in vitro associated with delayed type hypersensitivity. Science; $153:$ \&0-82, 1966.

31) S $\phi$ borg, M. and Bendixen, G: Human leucocyte migration as a parameter of hypersensitivity. Acta Med. Scand ,; $181: 247-256,1967$.

32) Clausen. J.E.: Tuberculin-induced migration inhibition of human peripherat leucocytes in ugarose medium. Acta Allergol., $26: 56-80,1971$.

33) Carpenter, R. R., Barsales, P. B. and Gäuchan, R. P. : Antigen-induced inhibition of ceì migration in agar'gel, plasma clot and liquid media. J. Reticuloendothel. Soc., 5:472-483, 1968.

34) McCoy, J. L., Jerome, L. F., Dean, J.H., Cannon, G. B., Alford, T. C., Doering, T. and Herberman. R. B.: Inhibition of leucocyte migration by tumor-associated antigens in soluble extracts of human breast "earcinoma. J. Natl. Cancer Inst., 53:11-17, 1974.

35) Meltzer, M. S., Oppenheim, J.J., Littman, B. H., Leonard, E. J. and Rapp; H. J.: Cell mediated tumor immunity measured in vitro and in vivo with soluble tumor specific antigens. J. Natl. Cancer Inst. $49: 727-734,1972$. 
36) Sфborg, M.: In vitro migration of peripheral human leucocytes in cellular hypersensitivity. Acta. Med. Scand., $184: 135-139,1968$.

37) Wahl, S. M., Altman, L. C. and Rosenstreich, D. L. : Inhibition of in itro lymphokine synthesis by glucocorticosteroids. J. Immunol., 115:476-481, 1975.

38) Rocklin, R. E.: Products of activated by Iymphocytes: Leucocyte inhibitory tactor (LIF) distinct from migration inhibitory factor (MIF). J. Immunol., 112:1461-1466, 1974.

39) Vincent, P. C. and Gunz, F. W.: Control of Iymphocyte Ievel in the blood. Lancet, $2: 342-$ $344,1970$.

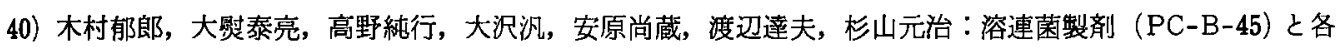
種制癌剂併用の試み. 癌の臨床, 18:886-891，1972。

41）木村郁郎：抗がん殽と容連菌剤の併用.最新医学, $28 ： 941-951 ， 1973$. 


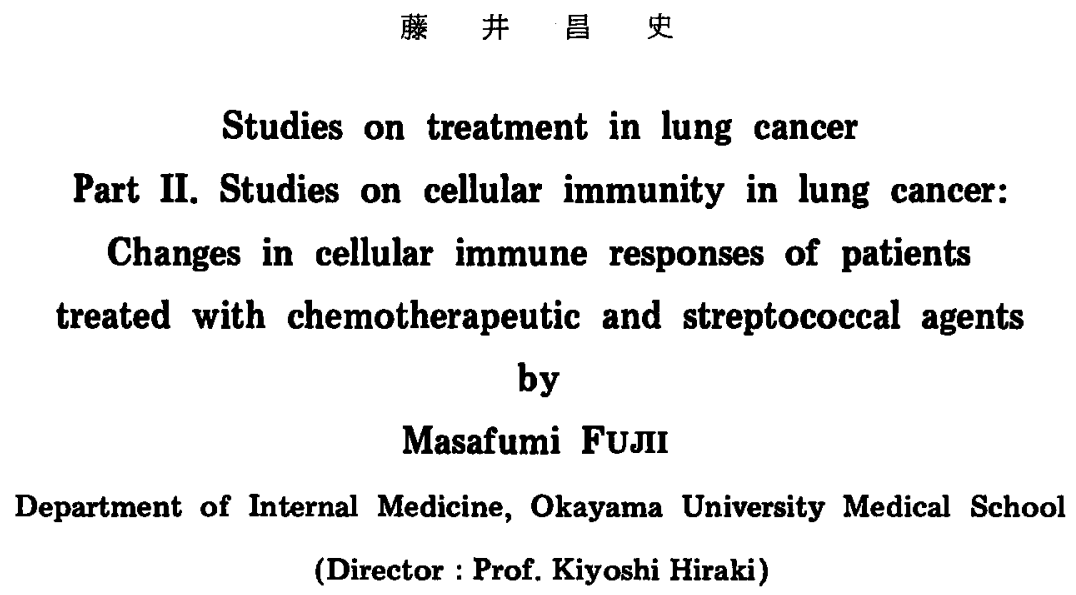

Studies on treatment in lung cancer

Part II. Studies on cellular immunity in lung cancer:

Changes in cellular immune responses of patients

treated with chemotherapeutic and streptococcal agents

by

Masafumi FUJI

Department of Internal Medicine, Okayama University Medical School

(Director : Prof. Kiyoshi Hiraki)

Cellular immunity in lung cancer was studied by means of lymphocyte transformation by phytohemagglutinin (PHA), purified protein derivative (PPD) skin test, absolute counts of peripheral lymphocytes and leucocyte migration inhibition test. The lymphocyte transformation by PHA was reduced in lung cancer patients in comparison with healthy controls, and correlated with the disease stage, but not with the histology type. The lymphocyte transformation became further depressed by cancer chemotherapy. PPD skin reaction or absolute counts of peripheral lymphocytes did not correlate with the disease stage. However, all the three tests correlated with the disease stage. Therefore, these tests appeared to be general indices of the immunologic status. Inhibition of leucocyte migration was demonstrated in about a half of the patients with lung cancer, but not in patients with other cancers or infectious lung diseases or in healthy controls. These findings suggest the presence of tumor-associated antigens in lung cancer. Concerning the effect of the streptococcal agent, OK-432, enhancement of the function of lymphocyte was observed in the parameters such as lymphocyte transformation by PHA, PPD skin test and leucocyte migration inhibition test. In addition, OK-432 yielded a longer survival in lung cancer patients when used in combination with chemotherapy than with chemotherapy alone. 